\title{
STATUS AKTA NOTARIS YANG DIBUAT OLEH NOTARIS YANG MERANGKAP JABATAN SEBAGAI ADVOKAT
}

\author{
Ragil Kusnaning Rini, Siti Romlah \\ Universitas Airlangga | Jl. Airlangga 4-6 Surabaya | rkusnaning@gmail.com
}

\begin{abstract}
Notary deed as an authentic deed is often used as a means of proof in a trial, because it is the most powerful and perfect. Considering the importance of a notarial deed as a means of proof, the making of a notary deed must be done properly and carefully. The phenomenon of notary that doubles the position as an advocate of course also affects the authentic deed that was made by the notary. A notary who concurrently serves as an advocate is considered to violate the provisions in the Act, so that the notary becomes unauthorized and no longer has power in making a notarial deed. That a deed which is due to the inability of the employee / official who made it or because of a defect in its form, then the deed cannot be treated as an authentic deed, and only has power as a deed under the hand if it is signed by the parties and is no longer has the power of proof that is perfect. For that, those who feel aggrieved can file a lawsuit and claim for compensation to the notary. And for violations of dual positions committed, if it is proven that the notary may also be subject to sanctions.
\end{abstract}

Keywords: Validation of Act, Notary, Duplicate of Department.

Abstrak: Akta notaris sebagai akta otentik seringkali dijadikan sebagai alat pembuktian di dalam persidangan, karena sifatnya yang paling kuat dan sempurna. Mengingat begitu penting akta notaris sebagai alat pembuktian, maka pembuatan akta notaris harus dilakukan dengan benar dan cermat. Adanya fenomena notaris yang merangkap jabatan sebagai advokat tentunya juga berpengaruh terhadap akta otentik yang telah dibuat notaris tersebut. Seorang notaris yang merangkap jabatan sebagai advokat dianggap melanggar ketentuan dalam Undang-Undang, sehingga notaris tersebut menjadi tidak berwenang dan tidak berkuasa lagi dalam membuat akta notaris. Bahwa suatu akta yang karena tidak berkuasanya pegawai/pejabat yang membuatnya atau karena suatu cacat dalam bentuknya, maka akta tersebut tidak dapat diperlakukan sebagai 
akta otentik, dan hanya mempunyai kekuatan sebagai akta dibawah tangan jika ditandatangani oleh para pihak dan bersifat tidak lagi mempunyai kekuatan pembuktian yang sempurna. Atas hal itu, bagi pihak yang merasa dirugikan dapat mengajukan gugatan dan tuntutan ganti rugi kepada notaris tersebut. Dan atas pelanggaran rangkap jabatan yang dilakukan, jika terbukti notaris tersebut juga dapat dijatuhi sanksi. Kata Kunci: Keabsahan Akta, Notaris, Rangkap Jabatan.

\section{Pendahuluan}

Seiring dengan perkembangan hukum dan kehidupan masyarakat Indonesia saat ini, jasa notaris menjadi sangat penting dalam pembuatan akta otentik, karena berbagai perbuatan maupun peristiwa hukum memerlukan bukti tertulis yang bersifat otentik yang bisa dijadikan alas hukum bagi seseorang dalam mempertahankan hak dan kewajibannya.

Pada prinsipnya suatu negara hukum akan menjamin kepastian, ketertiban, dan perlindungan hukum yang berintikan kebenaran dan keadilan. Kepastian, ketertiban, dan perlindungan hukum menuntut antara lain, bahwa lalu lintas hukum dalam kehidupan masyarakat memerlukan adanya alat bukti yang bisa menentukan dengan jelas antara hak dan kewajiban seseorang sebagai subyek hukum dalam masyarakat. ${ }^{1}$ Berbagai hubungan maupun kegiatan bisnis, baik di bidang perbankan, pertanahan, kegiatan sosial dan lain-lain, kebutuhan akan pembuktian secara tertulis berupa akta otentik semakin meningkat sejalan dengan berkembangannya tuntutan untuk menjamin perlindungan, ketertiban dan kepastian hukum bagi masyarakat. Melalui akta otentik inilah yang menentukan secara jelas tentang adanya hak dan kewajiban, menjamin kepastian hukum, sekaligus diharapkan pula untuk dapat dihindari terjadinya sengketa. $^{2}$

\footnotetext{
${ }^{1}$ Supriadi, Etika \& Tanggung Jawab Profesi Hukum di Indonesia, ( Jakarta: Sinar Grafika, 2016), 29 ${ }^{2}$ lbid
} 
Profesi notaris merupakan suatu pekerjaan yang membutuhkan suatu keahlian khusus dimana menuntut pengetahuan luas, kecermatan dan ketelitian serta tanggung jawab yang cukup berat untuk melayani kepentingan umum. Inti dari tugas notaris adalah mengatur serta menuangkan secara tertulis dan otentik hubungan-hubungan hukum antara para pihak yang secara mufakat meminta jasa notaris. ${ }^{3}$ Oleh karena itu, notaris sebagai profesi hukum tentunya dituntut untuk memiliki etika dan nilai moral yang tinggi. Berjalan atau tidaknya penegakan hukum dalam suatu masyarakat tergantung pada baik buruknya profesional hukum yang menjalani dan melaksanakan profesinya tersebut. Dan untuk menghindari supaya tidak sampai terjadi penyimpangan dalam menjalankan profesi tersebut, maka dibentuklah suatu norma yang wajib untuk dipatuhi, lazimnya disebut sebagai etika profesi. ${ }^{4}$

Pasal 15 ayat (1) Undang-Undang No. 2 Tahun 2014 tentang Perubahan Atas Undang-Undang No. 30 Tahun 2004 tentang Jabatan Notaris yang selanjutnya disebut dengan UUJN dijelaskan tentang kewenangan utama notaris yaitu membuat akta otentik mengenai semua perbuatan, perjanjian dan penetapan yang diharuskan oleh peraturan perundangundangan dan/atau yang dikehendaki oleh yang berkepentingan untuk dinyatakan dalam akta otentik, menjamin kepastian tanggal pembuatan akta, menyimpan akta, memberikan grosse, salinan dan kutipan akta, semuanya itu sepanjang pembuatan akta itu tidak juga ditugaskan atau dikecualikan kepada pejabat lain atau orang lain yang ditetapkan oleh undang-undang. ${ }^{5}$ Mengingat pentingnya peranan notaris dalam menciptakan kepastian dan perlindungan hukum bagi masyarakat, maka hubungan

\footnotetext{
${ }^{3}$ Ibid., 50.

${ }^{4}$ Ibid., 20-2I.

5 Pasal 15 ayat (I) Undang-Undang Nomor 2 Tahun 2014 tentang Perubahan Atas Undang-

Undang Nomor 30 Tahun 2004 tentang Jabatan Notaris
} 
yang baik antara notaris dan masyarakat juga harus dijaga, termasuk dalam hal pelayanan dan pembuatan akta otentik. Dalam praktek kehidupan bermasyarakat, seringkali kita temukan akta notaris yang dijadikan sebagai alat bukti dalam pemeriksaan perkara di persidangan, karena akta notaris ini merupakan akta otentik sebagai alat bukti tertulis dimana mempunyai kekuatan pembuktian yang sempurna dan mengikat. Oleh karena itu dalam pembuatan akta otentik seorang notaris dituntut untuk profesional, berhati-hati, tidak memihak, menguasai bidang hukum yang sedang ditanganinya dan harus sesuai dengan peraturan perundangundangan.

Notaris yang dianggap sebagai pejabat umum yang berwenang tentunya juga harus merujuk pada ketentuan yang ada dalam pasal-pasal UUJN yang mengatur seorang notaris harus mentaati segala kewajiban dan tidak melaksanakan segala larangan seperti yang diatur dalam UUJN. Sehingga pengawasaan dan pembinaan terhadap notaris sangat diperlukan agar tidak menyimpang dari aturan perundang-undangan dan kode etik profesi notaris serta sebagai upaya pencegahan terhadap terjadinya pelanggaran yang dapat merugikan masyarakat. Tetapi dalam prakteknya seringkali kita menjumpai adanya pelanggaran-pelanggaran baik yang menyimpang dari aturan UUJN maupun Kode Etik Notaris yang dilakukan oleh notaris. Misalnya tentang adanya notaris yang bekerja sambilan atau rangkap jabatan. Padahal dalam pasal 17 UUJN telah disebutkan dengan tegas terkait larangan notaris dalam hal rangkap jabatan. Namun meskipun begitu tidaklah gampang untuk menyeret perilaku notaris yang diduga melakukan rangkap jabatan tersebut ke ranah hukum. Dibutuhkan juga kerjasama dari masyarakat yang merasa dirugikan atas perilaku notaris tersebut untuk melaporkan ke Majelis Pengawas Notaris (MPN) tentunya dengan disertai bukti-bukti yang mendukung laporannya, 
setelah itu MPN akan bertindak dan melaksanakan pemeriksaan terhadap notaris yang dilaporkan tersebut. ${ }^{6}$

Bahwa seseorang untuk dapat menjadi notaris dibutuhkan jalan yang cukup panjang, mulai dari harus menyelesaikan pendidikan Strata-1 hukum dilanjutkan dengan Strata-2 Magister Kenotariatan, mengikuti pelatihan, ujian dan kemudian melakukan pemagangan di kantor notaris, tentunya bukan merupakan hal yang mudah. Calon notaris harus selalu belajar dan berpikir keras, menghabiskan banyak waktu dan mengeluarkan biaya yang tidak sedikit untuk bisa menjadi notaris. Sehingga tidak mengherankan jika seorang notaris akan mempunyai kemampuan dan keahlian yang mumpuni dalam bidang hukum. Bisa jadi karena merasa memiliki kemampuan dan keahlian tersebut ataukah ada faktor ekonomi yang melatarbelakanginya, maka terkadang kita menjumpai seorang notaris yang melanggar ketentuan dalam UUJN dan kode etik notaris dengan merangkap jabatan sebagai advokat dimana jelas-jelas hal itu dilarang dalam UUJN dan Kode Etik Notaris.

Apabila kemudian terdapat seorang notaris yang merangkap jabatan sebagai seorang advokat dan ada pihak lain yang merasa dirugikan atas perbuatan yang dilakukan oleh notaris tersebut, selanjutnya mengadukan kepada Majelis Pengawas Notaris beserta bukti-bukti pendukungnya, maka jika notaris tersebut terbukti melakukan rangkap jabatan seperti yang dilarang oleh UUJN, maka terhadap notaris tersebut akan dijatuhkan sanksi, dan tentunya akan ada akibat hukum yang terjadi atas akta yang telah dibuat oleh notaris tersebut. Karena seorang notaris yang merangkap jabatan ini telah melakukan suatu perbuatan atau tindakan yang dilarang oleh undang-undang. Untuk itulah penulis dalam hal ini tertarik untuk membahas terkait

${ }^{6}$ Sinaga Syamsudin Manan, Notaris Dilarang Rangkap Jabatan, (Hukum Online, 12 Februari 2019), Pukul I I:22. 
"Kedudukan akta otentik yang telah dibuat oleh notaris yang merangkap jabatan sebagai seorang advokat." Mengingat semakin banyaknya masyarakat yang menyadari pentingnya akta notaris sebagai akta otentik yang merupakan alat pembuktian paling penting dalam persidangan khususnya dalam perkara perdata.

\section{Akta Notaris Sebagai Akta Otentik}

Akta adalah bentuk surat atau tulisan yang dengan sengaja dibuat untuk dijadikan bukti tentang suatu peristiwa atau perbuatan dan ditandatangani oleh pembuatnya. Sehingga dapat dipahami bahwa suatu surat atau tulisan dapat dianggap sebagai akta jika memiliki ciri sengaja dibuat dan ditandatangani untuk dipergunakan oleh orang dan untuk keperluan siapa surat itu dibuat. ${ }^{7}$ Dalam masyarakat kita mengenal adanya dua macam akta yaitu akta otentik dan akta dibawah tangan. Bahwa suatu akta yang dibuat oleh atau dihadapan pejabat umum biasa dikenal dengan sebutan sebagai akta otentik. Notaris merupakan pejabat umum, sehingga semua akta yang dibuat oleh notaris dapat disebut juga sebagai akta otentik, asalkan akta tersebut memenuhi syarat otentiknya yaitu harus dibuat sesuai dengan bentuk dan tata cara yang diatur dalam undang-undang serta dibuat oleh atau dihadapan pejabat umum yang berwenang dalam hal ini adalah Notaris. Meskipun demikian, tidak berarti bahwa hanya notaris sajalah yang berwenang dalam membuat akta otentik, namun ada juga pihak-pihak lain yaitu pejabat umum lain yang juga berwenang dalam membuat akta otentik misalnya saja seperti pejabat kantor catatan sipil yang mengeluarkan surat kelahiran atau surat perkawinan, hakim yang mengeluarkan penetapan atau putusan, kepolisian yang mengeluarkan berita acara pemeriksaan dan lain sebagainya.

Akta Notaris merupakan akta otentik yang dibuat oleh atau dihadapan notaris secara khusus yang diatur dalam ketentuan Pasal

${ }^{7}$ Eddy O.S. Hiariej, Terori Hukum \&Hukum Pembuktian, (Jakarta: Erlangga, 20 I2), 82. 
1 angka 7 UUJN. Akta otentik sebagai alat bukti terkuat dan penuh mempunyai peranan penting dalam setiap hubungan hukum dalam kehidupan masyarakat. Berdasarkan undangundang, suatu akta otentik mempunyai kekuatan pembuktian yang sempurna, artinya jika suatu pihak mengajukan suatu akta otentik, maka hakim harus menerimanya dan menganggap apa yang sudah dituliskan di dalam akta itu sungguh-sungguh telah terjadi. ${ }^{8}$ Bahwa akta otentik ini dapat dijadikan sebagai alat pembuktian yang sempurna karena sifat dari akta otentik itu sendiri yang mana harus dibuat dalam bentuk yang diatur dan ditentukan oleh undang-undang, dimana jika dikaitkan juga dengan UUJN maka ada suatu keharusan bahwa dalam pembuatannya harus dilakukan oleh atau dihadapan pejabat umum yang berwenang.

Sedangkan akta dibawah tangan yaitu tiap akta yang tidak dibuat oleh atau dihadapan perantaraan seorang pejabat umum, yang mana akta itu dibuat dan ditandatangani sendiri oleh kedua belah pihak yang mengadakan perjanjian itu. Jika pihak yang menandatangani akta itu mengakui atau tidak menyangkal tandatangannya, berarti para pihak tersebut mengakui atau tidak menyangkal kebenaran mengenai hal yang tertulis dalam akta itu, sehingga akta dibawah tangan tersebut memperoleh suatu kekuatan pembuktian yang sama dengan suatu akta otentik. Namun sebaliknya jika tandatangan itu disangkal dan tidak diakui, maka pihak yang mengajukan akta tersebut diwajibkan untuk membuktikan kebenaran penandatanganan atau isi akta tersebut. ${ }^{9}$

Pengaturan tentang akta otentik diatur dalam pasal 1868 BW yang sekaligus menjadi dasar eksistensi dari akta notaris dimana terdapat syarat-syarat yang secara kumulatif harus dipenuhi yakni: a) Akta tersebut harus dibuat oleh atau dihadapan seorang pejabat umum yang berwenang.

b) Akta harus dibuat dalam bentuk yang diatur dan ditentukan oleh Undang-Undang.

\footnotetext{
${ }^{8} \mathrm{lbid.}$

${ }^{9}$ lbid., 83-84.
}

\section{\begin{tabular}{l|l}
38 & $\begin{array}{l}\text { al -Daulah } \\
\text { Vol. I0. no. I. April } 2020\end{array}$
\end{tabular}}


c) Akta tersebut dibuat oleh atau dihadapan pejabat umum yang berwenang untuk itu dan dimana tempat akta itu dibuat. ${ }^{10}$

Dalam dunia kenotariatan jenis akta dibagi menjadi dua, yang pertama adalah akta yang dibuat oleh notaris dikenal dengan nama akta relaas atau akta berita acara, yaitu akta yang berisi uraian tentang apa yang dilihat, didengar dan disaksikan sendiri oleh notaris, atas permintaan para pihak untuk dituangkan dalam sebuah akta notaris. Yang kedua adalah akta yang dibuat dihadapan notaris atas inisiatif dan permintaan para pihak yang dikenal dengan sebutan akta pihak, yaitu berisi keterangan atau pernyataan-pernyataan para pihak yang diceritakan dihadapan notaris, dan para pihak tersebut berkeinginan agar keterangannya tersebut dituangkan dalam akta notaris, sehingga notaris dalam hal ini hanya membantu untuk menetapkan atau memformulasikan apa saja yang diterangkan oleh para pihak penghadap tersebut.

Menurut Sudikno Mertokusumo, bahwa akta Notaris sebagai akta otentik mempunyai nilai kekuatan pembuktian secara lahiriah (Uitwendige Bewijskracht), Formal (Formele Bewijskracht) dan Materil (Materiele Bewijskracht).11 Nilai pembuktian lahiriah merupakan bentuk dari kemampuan akta itu sendiri untuk membuktikan keabsahannya sebagai akta otentik (acta publica probant sese ipsa). Jika dilihat dari luar (lahirnya) sebagai akta otentik serta sesuai dengan aturan hukum yang sudah ditentukan mengenai syarat akta otentik, maka akta tersebut berlaku sebagai akta otentik, sampai terbukti sebaliknya, artinya ada yang membuktikan bahwa akta tersebut bukan merupakan akta otentik secara lahiriah. ${ }^{12}$

Mengenai akta otentik juga diatur dalam HIR pasal 165, disebutkan bahwa akta otentik merupakan suatu akta yang dibuat oleh atau dihadapan pejabat yang diberi wewenang untuk itu, juga

\footnotetext{
10 Putu Mas Maya Ramantini, Tanggungjawab Notaris Dalam Pembuatan Minuta Akta Yang Dibuat Berdasarkan Keterangan Palsu Oleh Para Pihak, Tesis, (Denpasar: Fakultas Hukum Universitas Udayana, 20|4), 56.

" Sudikno Mertokusumo, Hukum Acara Perdata Indonesia, (Yogyakarta: Liberty, 1988), 123.

${ }^{12}$ Adjie Habib, Sanksi Perdata dan Administratif terhadap Notaris sebagai Pejabat Publik, (Bandung: Refika Aditama, 2009), 72.
} 
merupakan bukti yang lengkap antara para pihak dan para ahli warisnya dan mereka yang mendapat hak daripadanya tentang yang tercantum di dalamnya, dan bukan tentang yang tercantum sebagai pemberitahuan belaka, akan tetapi yang terakhir ini hanyalah sepanjang yang diberitahukan itu erat hubungannya dengan pokok daripada akta. ${ }^{13}$

Dari penjelasan beberapa pasal tersebut, maka bisa dimaknai bahwa suatu akta otentik ini dibuat oleh atau dihadapan pejabat yang berwenang yang disebut sebagai pejabat umum atas permintaan para pihak yang bersangkutan dan berdasarkan undang-undang. Pejabat umum yang dimaksud dalam hal ini adalah seorang Notaris. Sedangkan para pihak yang dimaksud adalah orang per orang atau badan hukum, yaitu pihak yang berkepentingan atas dibuatnya suatu akta tersebut. Terhadap akta otentik yang dibuat oleh Notaris harus dianggap sah dan mengikat bagi para pihak sebelum dapat dibuktikan ketidakabsahan dari akta otentik tersebut. Meskipun akta otentik yang dibuat oleh notaris dianggap mempunyai kekuataan pembuktian yang paling kuat dan sempurna, namun notaris juga harus tetap bertanggung jawab terhadap akta yang dibuatnya dan juga terhadap para pihaknya. Karena jika ada pihak-pihak yang merasa dirugikan atas terbitnya akta otentik tersebut bisa saja mengajukan gugatan atas kelalaian yang telah dilakukan oleh notaris tersebut.

\section{Akta Otentik Yang Tergradasi Menjadi Akta Dibawah Tangan}

Akta Notaris sebagai produk dari Pejabat Publik, maka penilaian terhadap akta Notaris harus dilakukan dengan asas praduga sah(vermoeden van Rechtmatigheid). ${ }^{14}$ Asas ini dapat dipergunakan untuk menilai akta Notaris, yaitu akta Notaris harus

\footnotetext{
${ }^{13}$ Herzien Inlandsch Reglement (HIR)

14 M. Hadjon Philipus, Pemerintah Menurut Hukum (Wet-en Rechtmatig Bestuur),( Surabaya: Yuridika, 1993), 5.
} 
dianggap sah sampai ada pihak yang menyatakan bahwa akta tersebut tidak sah. Dan untuk menyatakan atau menilai bahwa akta tersebut tidak sah yaitu melalui pengadilan, dimana para pihak itu sendiri ataupun pihak ketiga yang merasa keberatan dengan akta tersebut dapat mengajukan gugatan ke pengadilan. Selanjutnya hakim yang memeriksa gugatan tersebut yang nantinya akan memberikan penilaian tersendiri berdasarkan pembuktian dan penafsiran hakim apakah akta tersebut sah atau tidak.

Bahwa akta notaris sebagai akta otentik dapat turun atau terdegradasi menjadi akta dibawah tangan apabila melanggar ketentuan-ketentuan Pasal 16 ayat (1) huruf $m$ dan ayat (7), Pasal 38, Pasal 39, Pasal 40, Pasal 44 ayat (1), ayat (2), ayat (3) dan ayat (4), Pasal 48 ayat(1) dan ayat (2), Pasal 49 ayat (1) dan ayat (2), Pasal 50 ayat (1), ayat (2), ayat (3), dan ayat (4), Pasal 51 ayat (2) dalam UUJN. Telah disebutkan dengan jelas jika ketentuan yang diatur dalam pasal -pasal tersebut dilanggar maka mengakibatkan suatu akta hanya mempunyai kekuatan pembuktian sebagai akta dibawah tangan. Namun kedudukan hukum akta notaris yang dibuat oleh notaris yang merangkap jabatan sebagai advokat dimana hal tersebut dilarang dalam Pasal 17 ayat (1) huruf e UUJN tidaklah disebutkan.

Istilah tergradasi tersebut dalam akta notaris terjadi manakala akta notaris sebagai akta otentik yang mempunyai kekuatan pembuktian paling sempurna dan mengikat serta mencukupi batas minimal alat bukti yang sah tanpa diperlukan lagi alat bukti yang lainnya dalam sengketa hukum mengalami kemunduran, pemerosotan atau penurunan mutu yang mana posisinya menjadi lebih rendah dalam kekuatan sebagai alat bukti paling sempurna menjadi pembuktian seperti akta dibawah tangan dan memiliki kecacatan hukum yang bisa menyebabkan pembatalan atau ketidakabsahan dari akta notaris tersebut. ${ }^{15}$

Terhadap akta yang telah terlanjur dibuat oleh seorang notaris yang juga merangkap jabatan sebagai advokat, maka sifat dari akta

\footnotetext{
${ }^{15}$ Andre, P.R., Tanggung Jawab Notaris Terhadap Akta Yang Tergradasi Nilai Pembuktiannya Menjadi Akta Dibawah Tangan, (Doctoral Dissertation, Universitas Andalas: 20 I5)
} 
tersebut akan tergradasi menjadi akta dibawah tangan. Karena notaris tersebut telah melanggar ketentuan dalam pearaturan perundang-undangan, sehingga menyebabkan notaris tersebut menjadi tidak berwenang dan tidak berkuasa dalam membuat akta otentik. Namun sepanjang terjadinya degradasi dari akta otentik menjadi akta dibawah tangan tersebut tidak menimbulkan suatu kerugian, maka notaris yang bersangkutan tidak dapat dimintakan tanggung gugat hukumnya melalui ketentuan pasal 1365 BW. Namun sebaliknya, jika terjadinya degradasi akta otentik menjadi akta dibawah tangan tersebut mengakibatkan suatu kerugian, maka kepada pihak yang mengalami kerugian tersebut bisa mengajukan gugatan ganti rugi kepada notaris yang bersangkutan yaitu dengan cara membuktikan bahwa terjadinya kerugian tersebut merupakan akibat dari akta notaris yang telah tergradasi.

Berlakunya degradasi ini mengakibatkan bukti kekuatan pada suatu akta otentik berubah menjadi akta dibawah tangan pada umumnya terjadi sejak adanya putusan pengadilan yang telah mempunyai kekuatan hukum tetap (inkracht). Kedudukan akta dibawah tangan ini tetap sah dan mengikat, kecuali putusan pengadilan yang telah mempunyai kekuatan hukum tetap yang menyatakan batalnya akta tersebut atau tidak mengikatnya akta tersebut.

\section{Larangan Bagi Notaris yang Merangkap Jabatan Sebagai Advokat}

Notaris merupakan pejabat umum yang diangkat oleh negara mempunyai posisi yang strategis untuk melakukan tugas-tugas negara dalam rangka pelayanan hukum kepada masyarakat di bidang keperdataan khususnya mengenai pembuatan alat bukti berupa akta otentik demi tercapainya suatu perlindungan, ketertiban dan kepastian hukum di dalam masyarakat. Yang dimaksud dengan pejabat umum disini adalah orang yang diangkat untuk menduduki jabatan umum oleh penguasa untuk melakukan tugas negara atau pemerintah. Keberadaan Notaris merupakan pelaksanaan 
dari hukum pembuktian. ${ }^{16}$ Menurut Herlien Budiono, kewenangan Notaris yang utama adalah membuat akta otentik mengenai semua perbuatan, perjanjian, dan ketetapan yang diharuskan oleh peraturan perundang-undangan dan/atau yang dikehendaki oleh yang berkepentingan untuk dinyatakan dalam akta otentik, menjamin kepastian tanggal pembuatan akta, menyimpan akta, memberikan grosse, salinan dan kutipan akta, semuanya itu sepanjang pembuatan akta-akta tersebut tidak juga ditugaskan atau dikecualikan kepada pejabat lain atau orang lain atau orang lain yang ditetapkan oleh UUJN. ${ }^{17}$

Dalam pasal 15 ayat (1) UUJN ditegaskan bahwa kewenangan notaris adalah membuat suatu akta otentik dengan batasan-batasan:

1. Tidak ditugaskan atau dikecualikan kepada pejabat lain atau orang lain yang ditetapkan oleh undang-undang.

2. Akta otentik mengenai semua perbuataan, perjanjian, dan penetapan yang diharuskan oleh undang-undang dan/atau dikehendaki oleh yang berkepentingan.

3. Mengenai subyek hukum (orang atau badan hukum) untuk kepentingan dan kehendak siapa akta itu dibuat.

4. Berwenang atas tempat dimana akta itu dibuat, yang disesuaikan dengan tempat kedudukan dan wilayah jabatan notaris.

5. Menjamin kepastian waktu dalam pembuatan akta.

Dari batasan kewenangan tersebut, dapat dimaknai bahwa notaris mempunyai tugas dan kewajiban dalam menciptakan otentisitas dari suatu akta yang dibuat oleh atau dihadapannya dengan cara pemenuhan terhadap syarat-syarat yang telah ditentukan dalam undang-undang tersebut.

Notaris sebagai pejabat publik mempunyai kewenangan untuk membuat akta otentik dan akta lainnya. Akta otentik yang dibuat oleh notaris tersebut harus benar dan sesuai dengan peraturan

\footnotetext{
16 Budiono Herlin, Kumpulan Tulisan Hukum Perdata di Bidang Kenotariatan Buku Kedua, (Bandung: Citra Aditya Bakti, 20 I3), 220.

${ }^{17}$ Herlien Budiono, Dasar Teknik Pembuatan Akta Notaris, (Bandung: Citra Aditya Bakti, 20 I3), I.
} 
perundang-undangan yang berlaku. Di dalam menjalankan tugas dan kewenangannya, notaris tidak diperkenankan untuk melakukan kewenangannya di luar wilayah jabatannya, tidak boleh melakukan merangkap jabatan dan lain-lainnya. Apabila hal itu dilakukan oleh notaris, maka notaris tersebut dapat dikualifikasi melanggar larangan-larangan yang tercantum dalam undangundang. ${ }^{18}$ Larangan bagi notaris dikonsepkan sebagai aturan yang memerintahkan kepada notaris untuk tidak melakukan sesuatu yang bertentangan dengan peraturan perundang-undangan yang berlaku, dimana ada tiga unsur yang tercantum dalam konsep larangan diatas yaitu meliputi:

- Adanya aturan

- Adanya subyek, dan

- Hal-hal yang tidak boleh dilakukan oleh notaris. ${ }^{19}$

Walaupun akta notaris mempunyai kekuatan pembuktian yang sempurna, namun akta notaris itu juga dapat mempunyai kekuatan sebagai akta dibawah tangan atau akta yang batal demi hukum, dimana yang menjadi penyebab dari kekuatan pembuktian akta notaris menjadi akta dibawah tangan atau akta yang batal demi hukum adalah karena notaris tersebut telah lalai melakukan pelanggaran terhadap undang-undang. ${ }^{20}$

Ada beberapa larangan yang tidak boleh dilakukan oleh seorang notaris dalam menjalankan profesinya seperti yang tercantum dalam pasal 17 ayat (1) UUJN yaitu:

1. Menjalankan jabatannya diluar wilayah jabatannya,

2. Meninggalkan wilayah jabatannya lebih dari tujuh hari kerja berturut-turut tanpa alasan yang sah,

3. Merangkap sebagai pegawai negeri,

4. Merangkap jabatan sebagai pejabat negara,

5. Merangkap jabatan sebagai advokat,

18 Prof. Dr.H. Salim, HS., Peraturan Jabatan Notaris, (Jakarta: Sinar Grafika, 20 I 8), 208.

19 lbid., 209.

20 Ibid., 24l. 
6. Merangkap jabatan sebagai pemimpin atau pegawai badan usaha milik negara, badan usaha milik daerah atau badan usaha milik swasta,

7. Merangkap jabatan sebagai Pejabat Pembuat Akta Tanah dan/atau Pejabat Lelang Kelas II di luar tempat kedudukan Notaris,

8. Menjadi notaris pengganti, atau

9. Melakukan pekerjaan lain yang bertentangan dengan norma agama, kesusilaan atau kepatutan yang dapat mempengaruhi kehormatan dan martabat jabatan notaris.

Berdasarkan ketentuan dalam Pasal 17 ayat (1) UUJN tersebut, terdapat beberapa pekerjaan atau jabatan tertentu yang tidak boleh dirangkap oleh notaris yaitu: sebagai Pegawai Negeri Sipil (PNS), pejabat negara, advokat, pemimpin atau pegawai Badan Usaha Milik Negara (BUMN), pemimpin atau pegawai Badan Usaha Milik Daerah (BUMD), pemimpin atau pegawai badan usaha milik swasta. Jika larangan tersebut dilanggar oleh seorang notaris, maka berdasarkan ketentuaan Pasal 17 ayat (2) UUJN dapat dikenai sanksi berupa:

- Peringatan tertulis

- Pemberhentian sementara

- Pemberhentian dengan hormat, atau

- Pemberhentian dengan tidak hormat. ${ }^{21}$

Dalam hal ini pejabat yang berwenang menjatuhkan sanksi administratif terhadap notaris yang melakukan pelanggaran teerhadap UUJN terdiri atas:

1. Majelis Pengawas Wilayah,

2. Majelis Pengawas Pusat, dan

3. Menteri Hukum dan Hak Asasi Manusia,

Majelis Pengawas Wilayah berwenang memberikan:

1. Sanksi peringatan tertulis pertama,

2. Sanksi peringatan tertulis kedua,

3. Sanksi peringatan tertulis ketiga,

2I Pasal 17 ayat (I) ayat (2) Undang-Undang Nomor 2 Tahun 2014 tentang Perubahan Atas Undang-Undang Nomor 30 Tahun 2004 tentang Jabatan Notaris, op.cit. 
4. Berwenang untuk mengusulkan pemberhentian sementara kepada Majelis Pengawas Pusat Notaris

Majelis Pengawas Pusat berwenang untuk menjatuhkan sanksi pemberhentian sementara kepada notaris dan dapat juga mengusulkan kepada menteri berupa:

1. Pemberhentian dengan hormat, atau

2. Pemberhentian dengan tidak hormat

Menteri Hukum dan Hak Asasi Manusia berwenang untuk menjatuhkan:

1. Sanksi berupa pemberhentian dengan hormat, atau

2. Pemberhentian dengan tidak hormat kepada notaris. ${ }^{22}$

Selain disebutkan dalam UUJN, sanksi terhadap notaris yang merangkap jabatan juga diatur dalam Pasal 38 huruf e Peraturan Menteri Hukum dan Hak Asasi Manusia Republik Indonesia Nomor 25 Tahun 2014 Tentang Syarat dan Tata Cara Pengangkatan, Perpindahan, Pemberhentian, dan Perpanjangan Masa Jabatan Notaris dimana menjelaskan lebih lanjut ketentuan tentang notaris yang dapat diberhentikan dengan hormat dari jabatannya, apabila notaris tersebut merangkap jabatan sebagai pegawai negeri, pejabat negara, advokat, atau sedang memangku jabatan lain yang oleh Undang-Undang dilarang untuk dirangkap dengan jabatan notaris. ${ }^{23}$

Pada prinsipnya, seorang notaris harus bersikap netral, dimana harus berada ditengah-tengah dan tidak berpihak pada salah satu pihak manapun. Notaris harus bisa mengontrol dengan baik hubungan hukum antara para pihak dalam membuat suatu akta otentik yang sesuai dengan peraturaan perundang-undangan, sehingga tidak ada satu pihakpun yang akan dirugikan. Dalam prakteknya, seorang notaris tidak hanya bertugas membuat akta otentik saja, melainkan juga harus bisa memberikan layanan pemahaman dan nasehat hukum berkaitan dengan tugas dan

\footnotetext{
22 lbid,. 2 II-2I 2.

${ }^{23}$ Pasal 38 huruf e Peraturan Menteri Hukum dan Hak Asasi Manusia Republik Indonesia Nomor 25 Tahun 2014 Tentang Syarat dan Tata Cara Pengangkatan, Perpindahan, Pemberhentian, dan Perpanjangan Masa Jabatan Notaris.
} 
kewenangannya sesuai dengan peraturan perundang-undangan. Adanya seorang notaris yang merangkap jabatan sebagai advokat jelas dilarang, karena dikuatirkan dapat membuat notaris menjadi tidak netral dan kehilangan fokus dalam menjalankan tugas dan kewenangannya melayani masyarakat, sehingga bisa berakibat menimbulkan kerugian bagi masyarakat dan juga notaris itu sendiri. Notaris yang merangkap jabatan sebagai advokat akan lebih mendahulukan kepentingan pihak yang dapat memberi keuntungan bagi si notaris tersebut. ${ }^{24}$ Dari uraian diatas, maka larangan rangkap jabatan bagi notaris dapat dimaknai sebagai upaya pencegahan (preventif) agar tidak terjadi benturan kepentingan dan tentunya untuk menjaga netralitas dan profesionalitas notaris dalam melaksanakan tugas dan kewenangannya, sehingga profesi notaris akan tetap dipercayai oleh masyarakat.

Notaris yang merangkap jabatan sebagai advokat dalam ketentuan pasal 17 ayat (1) huruf e UUJN dengan tegas dilarang, termasuk penjatuhan sanksi terhadap notaris yang rangkap jabatan tersebut juga diatur dalam ayat (2). Namun akibat hukum terhadap akta yang telah dibuat oleh notaris yang merangkap jabatan sebagai advokat tersebut belum diatur dan disebutkan dengan jelas dalam UUJN. Sehingga dalam menganalisis kedudukan akta notaris yang telah dibuat oleh notaris yang merangkap jabatan sebagai advokat melalui cara pendekatan peraturan perundang-undangan, dimana dilakukan dengan cara menelaah semua peraturan perundangundangan dan regulasi yang berkaitan dengan kedudukan dan keabsahan akta notaris.

Dalam Pasal 1 UUJN disebutkan bahwa Notaris merupakan pejabat umum yang diberi wewenang untuk membuat akta otentik. Sedangkan dalam pasal 3 UUJN disebutkan pula bahwa untuk dapat menjadi seorang notaris maka salah satu syaratnya adalah tidak berstatus sebagai advokat dan tidak memangku jabatan lain

\footnotetext{
${ }^{24}$ Rifiani Nisya dan Sulihandari Hartanti, Prinsip-Prinsip Dasar Profesi Notaris,Cetakan I, (Jakarta (Jakarta: Dunia Cerdas, 20 I3), 108.
} 
yang oleh Undang-Undang dilarang untuk dirangkap dengan jabatan notaris.

Dari ketentuan beberapa pasal diatas maka dapat dianalisa bahwa seseorang yang berstatus advokat atau sedang memangku suatu jabatan tertentu yang dilarang oleh undang-undang, maka tidak dapat diangkat menjadi seorang notaris. Dan seorang notaris yang merangkap jabatan sebagai advokat dianggap melanggar ketentuan dalam Undang-Undang khususnya Pasal 17 ayat (1) UUJN, sehingga terhadap notaris tersebut diaanggap menjadi tidak berwenang dan tidak berkuasa lagi dalam membuat akta notaris. Hal ini jika dikaitkan dengan ketentuan dalam pasal 1869 BW dimana disebutkan bahwa terhadap suatu akta yang karena tidak berkuasanya pegawai/pejabat yang membuatnya atau karena suatu cacat dalam bentuknya, maka akta tersebut tidak dapat diperlakukan sebagai akta otentik, dan hanya mempunyai kekuatan sebagai akta dibawah tangan jika ditandatangani oleh para pihak. Sehingga kedudukan akta yang telah dibuat seorang notaris yang merangkap jabatan tersebut bisa tergradasi menjadi akta dibawah tangan dan bersifat tidak lagi mempunyai kekuatan pembuktian yang sempurna.

\section{Notaris Yang Merangkap Jabatan Sebagai Advokat Melanggar Kode Etik Notaris}

Profesi adalah peran sosial yang eksistensi atau keberadaannya serta fungsinya tergantung pada pelayanan yang fair atas kepentingan masyarakat. ${ }^{25}$ Profesi Notaris merupakan profesi terhormat (officium nobile) yang dalam menjalankan kewenangannya tentu harus sesuai dengan norma dan kaidah seperti yang diatur dalam UUJN dan kode etik notaris. Notaris merupakan profesi hukum yang dalam menjalankan kewenangannya sebagai pejabat umum harus sesuai dengan UUJN dan kode etik profesi. Dimana dalam Kode Etik Notaris

\footnotetext{
${ }^{25}$ Winarta Frans Hendra, Dialektika Pembaruan Sistem Hukum Indonesia, (Jakarta: Sekretariat Jendral Komisi Yudisial Republik Indonesia, 20 I2), 73.
} 
khususnya pada Bab III disebutkan terkait Kewajiban, Larangan dan Pengecualian yang tentunya harus ditaati oleh Notaris dalam melaksanakan jabatannya. Kode Etik Notaris ini merupakan suatu kaidah moral yang ditentukan oleh Perkumpulan Ikatan Notaris Indonesia (INI), dimana INI merupakan satusatunya organisasi notaris yang diakui oleh Undang-Undang yang mengatur tentang ketentuan yang berlaku dan wajib ditaati dalam menjalankan tugas dan jabatannya sebagai notaris. Sehubungan dengan kewenangan yang dimiliki oleh seorang notaris dalam membuat akta otentik, maka terhadap notaris tersebut dapat dibebani tanggung jawab atas perbuatan/pekerjaannya dalam membuat akta otentik. Oleh karena itu dalam membuat akta seorang notaris dituntut ketelitan, kecermatan dan kehati-hatian.

Seorang notaris yang merangkap jabatan harus mampu mempertanggungjawabkan perbuatannya dengan menerima sanksi seperti yang disebutkan dalam Pasal 17 ayat (2) UUJN. Selain melanggar UUJN, notaris yang merangkap jabatan sudah pasti juga melanggar kode etik notaris yang termuat pada Bab III tentang Kewajiban, Larangan dan Pengecualian, khususnya pada Pasal 3 angka:

1. Memiliki moral, akhlak serta kepribadian yang baik,

2. Menghormati dan menjunjung tinggi harkat dan martabat jabatan notaris

3. Menjaga dan membela kehormatan perkumpulan

4. Berperilaku jujur, mandiri, tidak berpihak, amanah, seksama, penuh tanggung jawab, berdasarkan peraturan perundang-undangan dan isi sumpah jabatan notaris. ${ }^{26}$

Seorang notaris yang merangkap jabatan sebagai advokat jika dihubungkan dengan ketentuan Pasal 3 angka (1), (2), (3), dan (4) Kode Etik Notaris, maka bisa dimaknai bahwa notaris tersebut tidak memiliki moral, akhlak, dan kepribadian yang baik, tidak jujur, tidak mandiri, tidak amanah, tidak bertanggung jawab dan tentunya tidak profesional dalam menjalankan tugas dan

${ }^{26}$ Kode Etik Notaris Tahun 2015 
kewenangannya, serta tidak menghormati dan menjunjung tinggi harkat dan martabat jabatan notaris serta tidak bisa menjaga dan membela kehormatan perkumpulan, karena dengan merangkap jabatan sebagai advokat, maka perbuatan notaris tersebut tidak berdasarkan peraturan perundang-undangan dalam hal ini UUJN dan juga tidak berdasarkan isi sumpah jabatan notaris. Sehingga terhadap notaris yang melakukan pelanggaran terhadap kode etik notaris dapat dikenai sanksi seperti yang disebutkan dalam Pasal 6 yaitu bisa berupa:

1. Teguran,

2. Peringatan,

3. Pemberhentian sementara dari keanggotaan perkumpulan,

4. Pemeberhentian dengan hormat dari keanggotaan perkumpulan,

5. Pemberhentian dengan tidak hormat dari keanggotaan perkumpulan. ${ }^{27}$

Dalam Pasal 1 angka 12 Kode Etik Notaris, sanksi tersebut merupakan suatu hukuman yang dijatuhkan oleh Dewan Kehormatan kepada notaris yang terbukti melakukan pelanggaran. Penjatuhan sanksi tersebut adalah sebagai upaya, sarana dan alat paksa terhadap ketaatan dan disiplin anggota perkumpulan yang sedang memangku dan menjalankan jabatan notaris. ${ }^{28}$

\section{Penutup}

Kewenangan utama seorang Notaris adalah membuat akta mengenai semua perbuatan, perjanjian, dan ketetapan yang diharuskan oleh peraturan perundang-undangan dan/atau yang dikehendaki oleh yang berkepentingan untuk dinyatakan dalam akta otentik. Akta notaris seringkali dijadikan sebagai alat bukti tertulis dalam pemeriksaan perkara di persidangan, karena mempunyai kekuatan pembuktian yang paling sempurna dan mengikat.

\footnotetext{
${ }^{27} \mathrm{Ibid}$

${ }^{28} \mathrm{lbid}$
} 
Apabila terdapat seorang notaris yang merangkap jabatan sebagai seorang advokat, maka terhadap notaris tersebut akan dijatuhkan sanksi, karena notaris yang merangkap jabatan ini telah melakukan suatu perbuatan atau tindakan pelanggaran terhadap apa yang telah diatur dalam UUJN dan Kode Etik Notaris.

Karena melanggar Undang-Undang dan ketentuan lainnya, maka notaris tersebut menjadi tidak berwenang dan tidak berkuasa lagi dalam membuat akta notaris. Menurut ketentuan pasal 1869 BW bahwa terhadap suatu akta yang karena tidak berkuasanya pegawai/pejabat yang membuatnya atau karena suatu cacat dalam bentuknya, maka akta tersebut tidak dapat diperlakukan sebagai akta otentik, dan hanya mempunyai kekuatan sebagai akta dibawah tangan jika ditandatangani oleh para pihak. Sehingga kedudukan akta yang telah dibuat seorang notaris yang merangkap jabatan tersebut bisa tergradasi menjadi akta dibawah tangan dan bersifat tidak lagi mempunyai kekuatan pembuktian yang sempurna. Jika dari perbuatan notaris tersebut, ada pihak-pihak yang merasa dirugikan, maka bisa menuntut ganti rugi kepada notaris tersebut, tentunya dengan membuktikan bahwa terjadinya kerugian tersebut merupakan akibat dari akta notaris yang telah tergradasi.

Dari tulisan ini, kiranya bisa dijadikan masukkan bagi para notaris agar lebih berhati-hati, disiplin dan tetap profesional dalam menjalankan kewenangannya supaya tidak merugikan notaris itu sendiri dan juga tidak merugikan orang lain. Sehingga kepercayaaan masyarakat terhadap profesi notaris akan selalu tetap terjaga.

\section{Daftar Pustaka}

Budiono, Herlien, Dasar Teknik Pembuatan Akta Notaris, (Bandung: Citra Aditya Bakti, 2013), 1. 
Burgelijk Wet Book (BW)

Habib, Adjie. Sanksi Perdata dan Administratif terhadap Notaris sebagai

Pejabat Publik, (Bandung: Refika Aditama, 2009), 72.

Hartanti Sulihandari, Rifiani Nisya. Prinsip-Prinsip Dasar Profesi

Notaris, Cetakan I, (Jakarta: Dunia Cerdas, 2013), 108.

Hendra, Winarta Frans. Dialektika Pembaruan Sistem Hukum Indonesia, (Jakarta: Sekretariat Jendral Komisi Yudisial Republik Indonesia, 2012), 73.

Herlin, Budiono. Kumpulan Tulisan Hukum Perdata di Bidang Kenotariatan Buku Kedua, (Bandung: Citra Aditya Bakti, 2013), 220.

Herzien Inlandsch Reglement (HIR)

Hiariej, Eddy O.S. Terori Hukum EHukum Pembuktian, (Jakarta: Erlangga, 2012), 82

HS, H. Salim. Peraturan Jabatan Notaris, (Jakarta: Sinar Grafika, 2018), 208.

Kode Etik Notaris Tahun 2015

Manan, Sinaga Syamsudin. Notaris Dilarang Rangkap Jabatan, (Hukum Online, 12 Februari 2019), Pukul 11:22.

Mertokusumo, Sudikno. Hukum Acara Perdata Indonesia, (Yogyakarta: Liberty, 1988), 123.

Peraturan Menteri Hukum dan Hak Asasi Manusia Republik Indonesia Nomor 25 Tahun 2014 Tentang Syarat dan Tata Cara Pengangkatan, Perpindahan, Pemberhentian, dan Perpanjangan Masa Jabatan Notaris.

Philipus, M. Hadjon. Pemerintah Menurut Hukum (Wet-en Rechtmatig Bestuur),( Surabaya: Yuridika, 1993), 5.

P.R, Andre. Tanggung Jawab Notaris Terhadap Akta Yang Tergradasi Nilai Pembuktiannya Menjadi Akta Dibawah Tangan, (Doctoral Dissertation, Universitas Andalas: 2015)

Ramantini, Putu Mas Maya. Tanggungjawab Notaris Dalam Pembuatan Minuta Akta Yang Dibuat Berdasarkan Keterangan Palsu Oleh Para Pihak, Tesis, (Denpasar: Fakultas Hukum Universitas Udayana, 2014), 56. 
Supriadi, Etika $\mathcal{E}$ Tanggung Jawab Profesi Hukum di Indonesia, ( Jakarta: Sinar Grafika, 2016), 29

Undang-Undang Nomor 2 Tahun 2014 tentang Perubahan Atas Undang-Undang Nomor 30 Tahun 2004 tentang Jabatan Notaris 